\title{
Diversity and distribution of myxomycetes in coastal and mountain forests of Lubang Island, Occidental Mindoro, Philippines
}

\author{
Macabago $\mathrm{SAB}^{1,2}$, Stephenson $\mathrm{SL}^{3}$, and dela Cruz $\mathrm{TEE}^{1,2}$ \\ ${ }^{1}$ The Graduate School and ${ }^{2}$ Fungal Biodiversity and Systematics Group, Research Center for the Natural and Applied \\ Sciences, University of Santo Tomas, Manila 1015 Philippines \\ ${ }^{3}$ Department of Biological Sciences, University of Arkansas, Fayetteville 72701 Arkansas, USA
}

Macabago SAB, Stephenson SL, dela Cruz TEE. 2016 - Diversity and distribution of myxomycetes in coastal and mountain forests of Lubang Island, Occidental Mindoro, Philippines. Mycosphere 7(1), 18-29, Doi 10.5943/mycosphere/7/1/2

\begin{abstract}
A study of the distribution and ecology of myxomycetes (plasmodial slime molds or myxogastrids) was carried out in the coastal and mountain forests of the geographically isolated island of Lubang in Occidental Mindoro of the Philippines. A total of 44 species were identified from moist chamber cultures. Arcyria cinerea, D. leucopodia, D. effusum, L. scintillans, and P. cinereum were the most abundant species recorded. Most species were commonly associated with only one of the substrates examined in two forest types. The highest level of productivity (myxomycetes recorded as either plasmodia or fruiting bodies) and the highest value for taxonomic diversity were observed for samples of ground litter collected from the mountain forests. However, the highest yield of fruiting bodies was noted for samples of the same substrate collected from the coastal forests. Assemblages of myxomycetes on Lubang Island were found to be similar within a particular area or forest type. This study is the first to compare the diversity and distribution of myxomycetes from two island forest types in the Philippines.
\end{abstract}

Key words - forest types - myxomycete ecology - S/G ratio

\section{Introduction}

Although a major portion of the biodiversity of the planet is concentrated in tropical regions, the relative abundance and taxonomic richness of myxomycetes have been only roughly estimated. Little is known about the status of myxomycete biodiversity, although these organisms might be expected to flourish in tropical countries because of their seemingly ideal location and resultant climatic conditions relating to temperature and moisture, which are thought to be the major factors determining the distribution of myxomycetes in nature. In Southeast Asia, most of the published literature consists of species list and until recently were limited to collecting carried out in Myanmar and Thailand (Reynolds \& Alexopoulos 1971), with only a few records from other countries in the region. Recently, Tran et al. (2006) surveyed the area around Chiang Mai in Northern Thailand and collected 62 species of myxomycetes representing 18 genera. From three lowland tropical forests in Vietnam, Tran et al. (2014) also recorded 43 species of myxomycetes representing 19 genera. In the Philippines, an annotated checklist of species known from the 
country was published by Reynolds (1981) more than 30 years go. In this checklist, the records of myxomycetes reported were based on collections made by Reynolds and from earlier studies in Davao, Cotabato and Zamboanga by E. B. Copeland; in Benguet by A. D. E. Elmer; and in Bataan, Manila, Cavite, and Laguna by E. D. Merrill. These collections are currently housed in the British Museum in London. Uyenco (1973) collected 314 specimens from Quezon City, Laguna, Basilan, and Zamboanga during the period of 1961 to 1973 and identified 18 species belonging to 10 genera. Later, Dogma (1975) listed 46 species of myxomycetes from 20 genera and stated that Martin and Alexopoulos (1969) had already credited the Philippines with 22 species in their major monograph (The Myxomycetes) in 1969. More recent studies of myxomycetes in the Philippines have included those of Macabago et al. (2010), Dagamac et al. (2012, 2014, 2015a, 2015b), Kuhn et al. (2013a, 2013b), Cheng et al. (2013), dela Cruz et al. (2014), and Alfaro et al. (2015).

National parks and protected areas serve as some of the few remaining habitats catering to the propagation of endangered species of plants and animals. However, only $7.8 \%$ of the total land area in the Philippines is listed in the protected area categories (Ong et al. 2002). Therefore, the Philippine government has established conservation programs for the few remaining endangered and rare species left in its rapidly disappearing rainforests. This consciousness has spread among people who realize the need to conserve natural resources, as in the case of the Verde Passage in the province of Batangas. The Verde Passage Marine Biodiversity Conservation Corridor (MBCC) is considered to be an area with one of the very highest levels of marine biodiversity for any tropical water territory on earth. However, there are considerable dangers to this area due to habitat damage and inadequately planned coastal resources development. The Lubang group of Islands, bounded on the west by vast the South China Sea and on the south by the Calavite Passage, is part of the Verde Passage that is greatly protected for its coastal and mountain ecosystems. The Department of Environment and Natural Resources (DENR) of the Philippines identified the island as one of the biodiversity conservation priority terrestrial areas, with an extremely high critical priority level (Ong et al. 2002). Although isolated islands such as Lubang Island potentially represent living laboratories for studies of biogeography, relatively less is known about their biota-the flora and fauna, including the microbial flora. Thus, in this protected area, many new species continue to be discovered. Due to the unique habitats present on Lubang Island, the study reported herein investigated the distribution and ecology of myxomycetes in the coastal and mountain forests of Lubang Island, Occidental Mindoro. Macabago et al. (2012) reported a species list of myxomycetes from Lubang Island. The present paper is an ecological analysis of the data represented by the collections reported in the earlier paper.

\section{Materials \& Methods}

The present study was carried out in two different types of forests. The first type is the coastal forest, with this term referring to the fact that the collecting areas are located near the periphery of the island but are not mangrove forests. The second type of forest is the mountain forest in which collecting sites were situated on Mt. Gonting, located at the center of the island (Fig. 1). The methods used in collecting specimens of myxomycetes and the analysis of data follow those described in the literature (e.g., Stephenson \& Stempen 1994).

The Lubang group of islands, located at $13^{\circ} 47^{\prime \prime} \mathrm{N}, 120^{\circ} 12^{\prime \prime} \mathrm{E}$ and with a total land area of 6,918.78 ha, is composed of four islands near but isolated from the Island of Mindoro (Fig. 1). Their topography is generally characterized by a rugged terrain with narrow strips of coastal lowlands, a series of mountain ranges, valleys, and elongated plateaus, with rolling lands along the coastal region, as has been described by Macabago et al. (2012). As noted above, collecting sites in two distinct types of forest ecosystems (coastal forests and mountain forests) provided the substrates used to prepare moist chamber cultures.

Ten (10) samples each of dried, dead twigs (TW) and ground (mostly leaf) litter (GL) were collected from ten (10) sites along the periphery of Lubang Island (coastal forests) and ten (10) sites from two slopes of Mt. Gonting (mountain forests) during May 2009. 


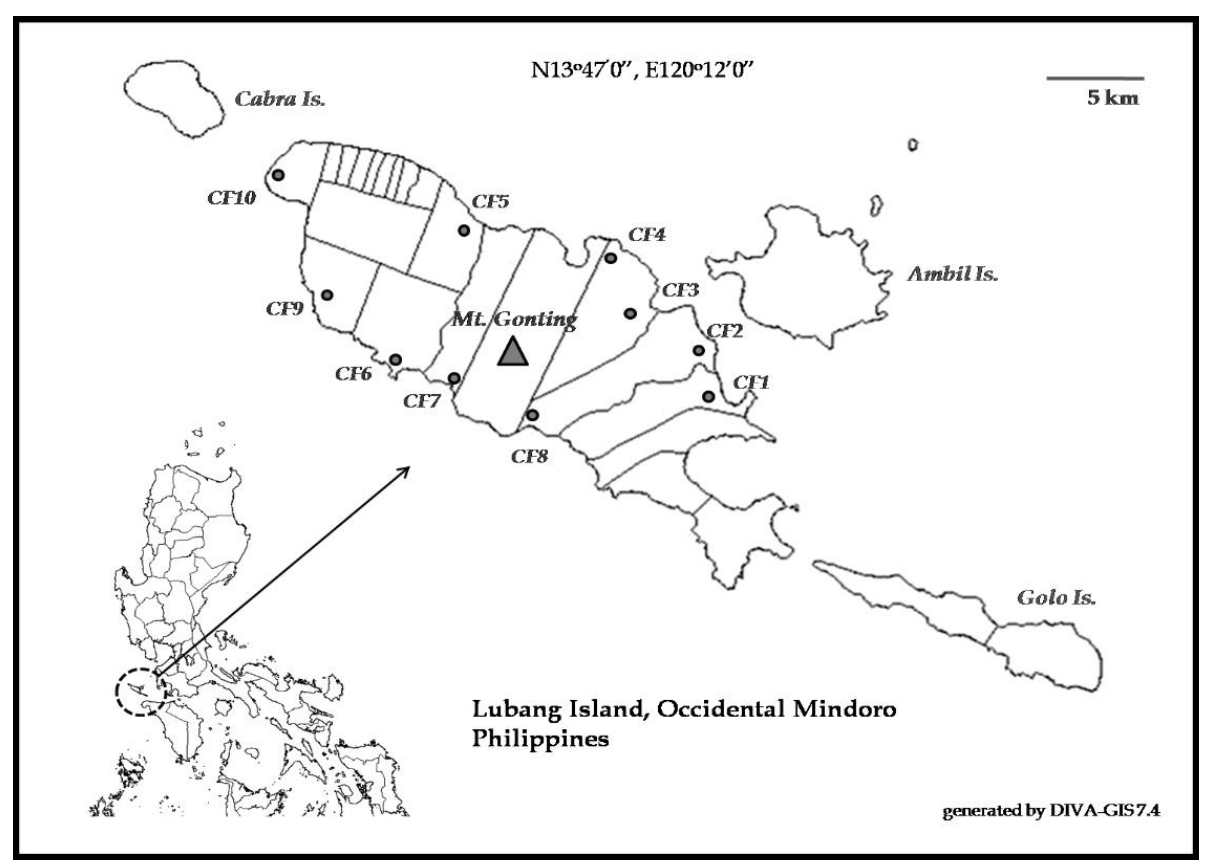

Fig. 1 - Collection sites on Lubang Island, Occidental Mindoro. Ten sites (indicated by the black dots) were located in coastal areas and ten sites (indicated by the black triangle) on Mt. Gonting (Macabago et al. 2012).

The samples of ground litter and twigs were air-dried and then used to prepare moist chamber cultures following the protocol described by Stephenson \& Stempen (1994). Moist chamber cultures (MC, in triplicates or three cultures per sample) were checked regularly for the presence of myxomycete plasmodia and/or fruiting bodies. Only cultures with fruiting bodies and/or plasmodia present were noted as positive. Following incubation, individually-collected fruiting bodies of myxomycetes with their respective substrates were placed in small pasteboard boxes, and these were labeled. Productivity of the moist chamber cultures was then assessed as described in Dagamac et al. (2012). Productivity was further assessed in relation to the "replication data" for moist chambers.

Fruiting bodies were identified using gross morphological characters of the fruiting bodies (e.g., the appearance of the capillitium, calyculus, stalk and presence or absence of lime) under a stereomicroscope (QZG series, USA \& Olympus CX21). Spore morphology was determined following the protocol of Keller \& Braun (1999). Morphometric data were compared with identification keys used in conjunction with the published literature (e.g., Martin \& Alexopoulos 1969, Stephenson \& Stempen 1994) and web-based electronic databases, (e.g., the Eumycetozoan Project [http://slimemold.uark.edu]). Nomenclature follows that available on the website http://nomen.eumycetozoa.com.

Ecological statistical analysis was used to determine and/or assess the diversity and distribution of the myxomycete assemblages on Lubang Island. Data used to calculate species diversity and other ecological values were based primarily on specimens obtained from moist chamber cultures. As used herein, occurrence refers to the overall frequency of each species of myxomycete based on its occurrence in moist chamber cultures. A moist chamber culture positive for the fruiting bodies of a particular species was considered as one positive collection. As such, each collection was considered as an individual unit. Thus, the data on the occurrence of each species in each collection site and on each substrate type were then compiled and expressed as relative abundance (RA). The relative abundance value assigned to each species was (1) "abundant" (A) if the relative abundance of the species in question was $\geq 3 \%$ of the total of all collections, (2) "common" (C) if the RA was $\geq 1.5 \%$ but $<3 \%$ of the total collections, (3) "occasional" $(\mathrm{O})$ if the RA was $\geq 0.5 \%$ but $<1.5 \%$ of the total of all collections, and (4) "rare" (R) if the RA was $<0.5 \%$ of the total for all collections. 
The series of specimens generated in the present study served as baseline data for the assessment of myxomycete ecology on Lubang Island. It was therefore necessary to estimate if the sampling was exhaustive. A species accumulation curve (SAC) was constructed using the program EstimateS version 8.2 (Colwell 2009). The Chao2 incidence-based estimator of species richness was used to construct the SAC, wherein a hyperbolic regression according to the Michaelis-Menten formula y $1 / 4 \mathrm{ax}=\varnothing \mathrm{b} \mathrm{p} \times \mathrm{P}$ was applied to the data, with the parameter providing an estimate for the maximum number of species to be expected (Novozhilov et al. 2013).

Initially, the number of species and genera for each forest type and substrate type were determined. A value for taxonomic diversity was then derived by calculating the ratio of the number of species to the number of genera ( $\mathrm{S} / \mathrm{G}$ ratio). A value for the $S / G$ ratio is inversely proportional to its taxonomic diversity. As such, the lower the S/G ratio, the more diverse a particular biota is considered. It is based on the premise that a biota in which the species are divided among many genera is "intuitively" more diverse in a taxonomic sense than one in which most species belong to only a few genera (Stephenson et al. 1993).

To provide another measure of assessing myxomycete diversity in each collecting site and for each type of substrate examined, species diversity was calculated as described in Dagamac et al. (2012). In contrast to taxonomic diversity, species diversity indices focus on species richness and evenness. The number of individuals is represented herein by the value for relative abundance. Pairwise comparisons of the myxomycete assemblages for the two forest types (coastal and mountain) and two types of substrates (ground litter and twigs) were carried out using the Sorensen's Coefficient of Community (CC) and the Percentage Similarity (PS) indices, as described by Stephenson (1989). The Coefficient of Community (CC) index is based only on the presence or absence of species in the two communities being compared. In contrast, the Percentage Similarity (PS) index considers not only the presence or absence of a species but also its relative abundance. The CC and PS values range from 0 to 1 . The higher the value, the more similar the communities are in terms of their species composition and abundance.

\section{Results}

Moist chamber productivity: A total of 1,188 moist chamber cultures were prepared from samples of ground litter and twigs randomly collected from 20 sites in the coastal and mountain forests of Lubang Island. From the cultures prepared, 829 (70\%) were positive for myxomycetes (i.e., plasmodia, sclerotia and/or fruiting bodies were observed to be present). Fruiting bodies were observed more often than plasmodia. The yield of myxomycetes was also compared between the two forest types and the two types of substrates. Substrates collected in the mountain forests yielded slightly more positive cultures $(71 \%)$ than substrates collected from the coastal forests $(69 \%)$. Between the two substrates, ground litter had a higher yield $(76 \%)$ than twigs. Higher yields for fruiting bodies $(56 \%)$ and plasmodia $(46 \%)$ also were observed for ground litter. There were several interesting differences in the myxomycetes appearing on the two types of substrates collected from the two distinct forest types. In general, higher myxomycete yield (71-80\%) was observed for ground litter regardless of the forest type. More plasmodia (38-54\%) also were noted for ground litter, again regardless of forest type. However, more fruiting bodies (59-61\%) were noted in samples of ground litter and twigs collected from the coastal forest. Although a high yield of plasmodia was observed for ground litter collected in the mountain forest, many of these never developed into fruiting bodies. As a result, a higher number of fruiting bodies was noted for ground litter collected in the coastal forests. All samples with ground litter or twigs were represented by three moist chamber cultures, which acted as replicates. To further assess the possible effect of replication, we also evaluated the moist chamber productivity in relation to the species present and the number of triplicate cultures. Results showed that only $150(38 \%)$ of the triplicate cultures or 450 individual moist chamber cultures displayed similar results (i.e., either having two to three cultures with the same species of myxomycetes or all three cultures producing no evidence of myxomycetes). More of the cultures, 246 (62\%) of the triplicate cultures or 738 individual cultures, showed dissimilar results. This means that two to three cultures of the "triplicates" had different 
species of myxomycetes present or only one plate among the triplicates yielded a particular myxomycete. Comparing the two types of substrates, the same trend was observed, such that 77 (39\%) triplicate cultures or 231 individual cultures with ground litter and 73 (37\%) triplicate cultures or 219 individual cultures with twig substrates yielded a particular species of myxomycetes.

Species occurrence, accumulation and relative abundance: A total of 44 species representing 13 genera were identified from ground litter and twigs collected from the two forest types (Table 1). Of these, 38 were recorded in the coastal forests, whereas 35 were recorded from the mountain forests. The species collected belong to four (4) taxonomic orders. These are the Liceales (two species), the Physarales (19 species), the Stemonitales (14 species) and the Trichiales (nine species). To estimate whether or not the number of samples collected was enough to reflect the diversity of myxomycetes in the study area, a species accumulation curve for the study sites was generated (Fig. 2). Values from this analysis indicate that the survey was $95.7 \%$ complete (i.e., the Chao 2 mean was 47 , compared to 44 actual morphospecies identified). Individual results from the two forest types produced a similar outcome, with the sampling effort for the mountain forests calculated as $97.9 \%$ complete, which was higher than the corresponding value for the coastal forests $(83.9 \%)$. As such, it can be assumed that the sampling effort was sufficient to recover the more common species of myxomycetes associated with the forest types studied on Lubang Island.

Species abundance also was calculated, based primarily on the relative abundance (RA) value for each species of myxomycete. Arcyria cinerea was the most abundant of all of the species collected. Diderma effusum was the second most abundant myxomycete species, followed by Physarum cinereum, Stemonitis fusca, Lamproderma scintillans, and Diachea leucopodia. Fifteen species represented less than $0.5 \%$ of the total number of collections and thus were considered as rare. Slight differences in species occurrence and abundance were noted for the two forest types with more rare species recorded in coastal forests (Table 1). Thirty-eight species of myxomycetes were recorded from collecting sites in the coastal forest. Of these, only two species (Arcyria cinerea and $D$. effusum) were recorded as abundant. Twenty one species were rare. In the collecting sites in the mountain forest, $A$. cinerea, D. effusum, and $P$. cinereum (considered as abundant) were the most commonly collected of the 35 species. Thirteen species were recorded either as rare or occasional. There were more noticeable differences in species occurrence and abundance when the two types of substrates (ground litter and twigs) were compared (Table 1). Twenty-one species were common to both substrate types. Thirty-four species were recorded from ground litter, whereas four fewer species were recorded for twigs. Arcyria cinerea was the most abundant species on both ground litter and twigs, with D. leucopodia, D. effusum and P. cinereum also abundant on ground and S. fusca also abundant on twigs. Other species (14) were classified as rare on ground litter. Of the 30 species collected on twigs, 14 species were also classified as rare.

Species and taxonomic diversity: In the present study, 38 species representing 13 genera were recorded in the coastal forests, whereas only 35 species from the same number of genera were recorded for the mountain forests. Although there were more different species in the coastal forests, these belonged to the same number of genera as in the mountain forests. However, taxonomic diversity was lower in coastal forests as shown in its higher $S / G$ ratio (2.92). When comparing the taxonomic diversity of the two types of substrates, ground litter had a higher number of species (34) belonging to a higher number of genera (13), resulting to a lower S/G ratio (2.62) and thus a higher taxonomic diversity than twigs. Apart from the taxonomic diversity, species diversity also was assessed based on the richness and evenness of the myxomycete species in the two forest types and on the two substrates (Table 2). Myxomycetes in the mountain forests were found more even $(\mathrm{E}=$ 0.52) than in coastal forests. However, myxomycete species richness in the coastal forests was higher $(\mathrm{Hg}=6.16)$ than in the mountain forests. The overall diversity as reflected by the Shannon's diversity index (Hs) showed a higher value in mountain forests (1.27). Between the two substrates collected, minimal differences in species diversity were observed in this study. Higher evenness and richness, and thus higher species diversity, were noted for ground litter than for twigs (Table 2). 
Table 1 Abundance indices of myxomycetes on Lubang Island in relation to substrate type and the two forest types (coastal and mountain). Note: GL = ground litter and TW = twigs.

\begin{tabular}{|c|c|c|c|c|c|}
\hline Species & GL & TW & Coastal & Mountain & Total \\
\hline Arcyria afroalpina & $\mathrm{C}$ & $\mathrm{C}$ & $\mathrm{R}$ & $\mathrm{C}$ & $\mathrm{C}$ \\
\hline Arcyria cinerea & A & A & A & A & A \\
\hline Arcyria denudata & & $\mathrm{C}$ & $\mathrm{C}$ & $\mathrm{R}$ & $\mathrm{C}$ \\
\hline Arcyria globosa & $\mathrm{O}$ & $\mathrm{R}$ & $\mathrm{R}$ & $\mathrm{O}$ & $\mathrm{O}$ \\
\hline Arcyria pomiformis & $\mathrm{R}$ & $\mathrm{R}$ & $\mathrm{R}$ & & $\mathrm{R}$ \\
\hline Collaria arcyrionema & $\mathrm{O}$ & $\mathrm{R}$ & $\mathrm{R}$ & $\mathrm{O}$ & $\mathrm{O}$ \\
\hline Collaria rubens & $\mathrm{O}$ & & $\mathrm{R}$ & $\mathrm{R}$ & $\mathrm{O}$ \\
\hline Comatricha nigra & $\mathrm{R}$ & $\mathrm{R}$ & $\mathrm{R}$ & $\mathrm{R}$ & $\mathrm{O}$ \\
\hline Comatricha robusta & & $\mathrm{R}$ & $\mathrm{R}$ & & $\mathrm{R}$ \\
\hline $\begin{array}{l}\text { Comatricha } \\
\text { subcaespitosa }\end{array}$ & $\mathrm{O}$ & $\mathrm{O}$ & $\mathrm{O}$ & $\mathrm{O}$ & $\mathrm{R}$ \\
\hline Craterium atrolucens & $\mathrm{R}$ & & & $\mathrm{R}$ & $\mathrm{R}$ \\
\hline Craterium concinnum & $\mathrm{O}$ & & $\mathrm{R}$ & $\mathrm{O}$ & $\mathrm{O}$ \\
\hline Craterium sp. & $\mathrm{R}$ & & & $\mathrm{R}$ & $\mathrm{R}$ \\
\hline Cribraria microcarpa & & $\mathrm{C}$ & & $\mathrm{C}$ & $\mathrm{C}$ \\
\hline Cribraria sp. & $\mathrm{R}$ & & & $\mathrm{R}$ & $\mathrm{R}$ \\
\hline Diachea leucopodia & A & & $\mathrm{O}$ & $\mathrm{C}$ & A \\
\hline Diachea radiata & $\mathrm{R}$ & & $\mathrm{R}$ & & $\mathrm{R}$ \\
\hline Diderma effusum & A & $\mathrm{C}$ & A & A & A \\
\hline $\begin{array}{l}\text { Diderma } \\
\text { hemisphaericum }\end{array}$ & $\mathrm{O}$ & & $\mathrm{O}$ & $\mathrm{R}$ & $\mathrm{O}$ \\
\hline Didymium iridis & $\mathrm{O}$ & & $\mathrm{O}$ & $\mathrm{R}$ & $\mathrm{O}$ \\
\hline $\begin{array}{l}\text { Didymium } \\
\text { melanospermum }\end{array}$ & $\mathrm{O}$ & & $\mathrm{R}$ & $\mathrm{O}$ & $\mathrm{O}$ \\
\hline Didymium nigripes & $\mathrm{R}$ & & $\mathrm{R}$ & $\mathrm{R}$ & $\mathrm{R}$ \\
\hline $\begin{array}{l}\text { Didymium } \\
\text { ochroideum }\end{array}$ & $\mathrm{R}$ & $\mathrm{C}$ & $\mathrm{C}$ & $\mathrm{R}$ & $\mathrm{C}$ \\
\hline $\begin{array}{l}\text { Didymium } \\
\text { squamulosum }\end{array}$ & $\mathrm{O}$ & $\mathrm{O}$ & $\mathrm{O}$ & $\mathrm{O}$ & $\mathrm{C}$ \\
\hline $\begin{array}{l}\text { Lamproderma } \\
\text { cacographicum }\end{array}$ & $\mathrm{R}$ & & $\mathrm{R}$ & & $\mathrm{R}$ \\
\hline $\begin{array}{l}\text { Lamproderma } \\
\text { scintillans }\end{array}$ & $\mathrm{C}$ & $\mathrm{C}$ & $\mathrm{O}$ & $\mathrm{C}$ & A \\
\hline $\begin{array}{l}\text { unidentified } \\
\text { myxomycete }\end{array}$ & & $\mathrm{R}$ & $\mathrm{R}$ & & $\mathrm{R}$ \\
\hline Oligonema schwenitzii & $\mathrm{O}$ & & $\mathrm{R}$ & $\mathrm{O}$ & $\mathrm{O}$ \\
\hline Perichaena corticalis & & $\mathrm{O}$ & $\mathrm{R}$ & $\mathrm{O}$ & $\mathrm{O}$ \\
\hline Perichaena depressa & & $\mathrm{R}$ & $\mathrm{R}$ & & $\mathrm{R}$ \\
\hline $\begin{array}{l}\text { Perichaena } \\
\text { microspora }\end{array}$ & $\mathrm{O}$ & $\mathrm{R}$ & $\mathrm{R}$ & $\mathrm{O}$ & $\mathrm{O}$ \\
\hline Physarum bivalve & $\mathrm{O}$ & & $\mathrm{O}$ & & $\mathrm{O}$ \\
\hline Physarum cinereum & A & $\mathrm{C}$ & $\mathrm{C}$ & A & A \\
\hline $\begin{array}{l}\text { Physarum } \\
\text { compressum }\end{array}$ & $\mathrm{C}$ & $\mathrm{R}$ & $\mathrm{O}$ & $\mathrm{O}$ & $\mathrm{C}$ \\
\hline $\begin{array}{l}\text { Physarum } \\
\text { echinosporum }\end{array}$ & $\mathrm{O}$ & $\mathrm{C}$ & $\mathrm{O}$ & $\mathrm{C}$ & $\mathrm{C}$ \\
\hline Physarum melleum & $\mathrm{R}$ & $\mathrm{R}$ & $\mathrm{O}$ & & $\mathrm{O}$ \\
\hline Physarum oblatum & $\mathrm{R}$ & $\mathrm{O}$ & $\mathrm{O}$ & $\mathrm{R}$ & $\mathrm{O}$ \\
\hline Physarum viride & $\mathrm{R}$ & $\mathrm{R}$ & $\mathrm{R}$ & $\mathrm{R}$ & $\mathrm{R}$ \\
\hline Stemonitis axifera & $\mathrm{R}$ & $\mathrm{O}$ & & $\mathrm{O}$ & $\mathrm{O}$ \\
\hline Stemonitis fusca & $\mathrm{R}$ & A & $\mathrm{C}$ & $\mathrm{C}$ & A \\
\hline Stemonitis fusca var. nigrescens & & $\mathrm{R}$ & $\mathrm{R}$ & & $\mathrm{R}$ \\
\hline Stemonitis herbatica & & $\mathrm{R}$ & $\mathrm{R}$ & & $\mathrm{R}$ \\
\hline Stemonitis pallida & & $\mathrm{C}$ & $\mathrm{O}$ & $\mathrm{O}$ & $\mathrm{C}$ \\
\hline Stemonitis smithii & & $\mathrm{O}$ & $\mathrm{R}$ & $\mathrm{O}$ & $\mathrm{O}$ \\
\hline Stemonitis splendens & & $\mathrm{R}$ & & $\mathrm{R}$ & $\mathrm{R}$ \\
\hline
\end{tabular}




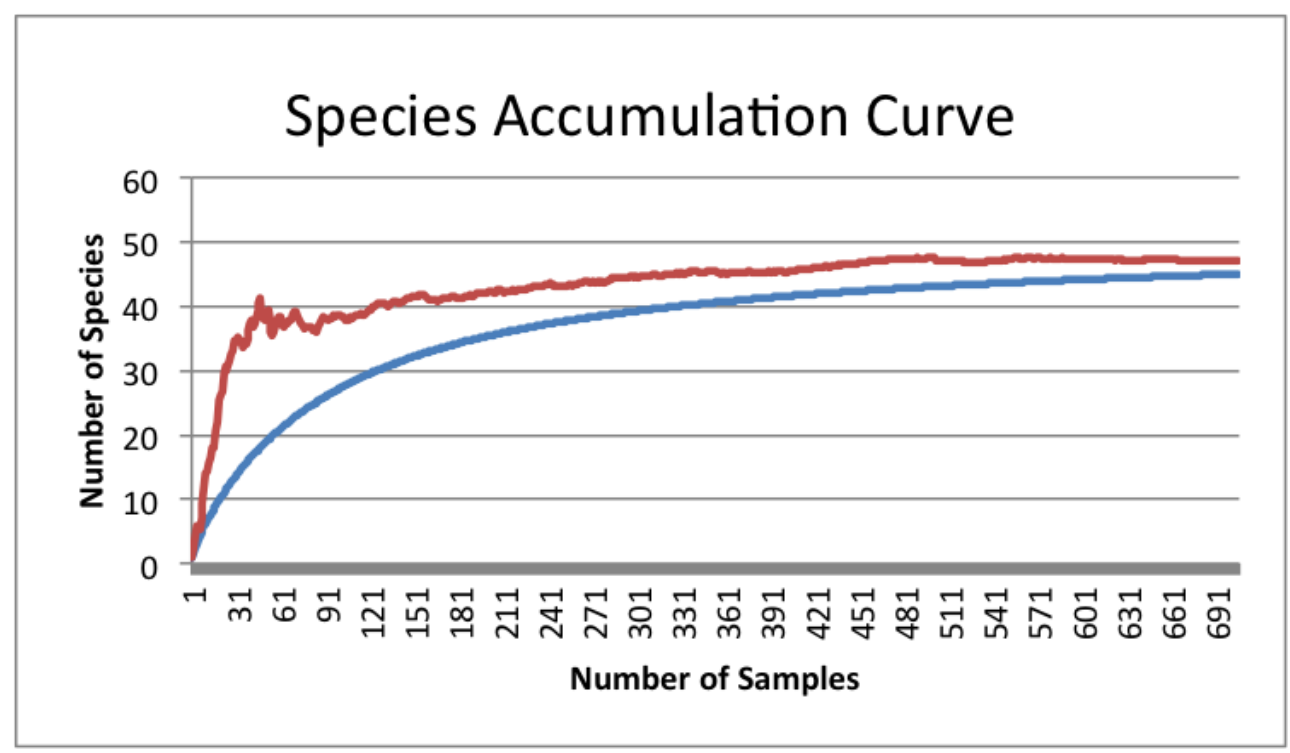

Fig. 2 - Species accumulation curve of myxomycetes on Lubang Island. The sample-species curve shows the accumulation of new species in relation to the number of samples collected. Note: Chao2 (Mean) estimator $=$ red/upper, Rarefaction curve $=$ blue/lower .

Distribution patterns and community analysis: When the myxomycete assemblages of the two forest types were compared, a CC value of 0.76 and PS value of 0.31 were derived. The former value indicates that more than $75 \%$ of the total species identified in both forest types were the same. Although there were 29 species collected in both forest types, those species shared in common mostly displayed a rare abundance, and only A. cinerea, D. effusum and P. cinereum were recorded as abundant or occasional in either or both coastal and mountain forests. Thus implies that the species were not present in equal abundance in both forest types. Some species that were restricted to a specific forest type also were recorded. Six species were found exclusively in the mountain forest, whereas ten species were recorded only in the coastal forest. More than half of the species occurring on ground litter also occurred on twigs. As was the case in the previous instance, the species found on both ground litter and twigs were not present in equal abundance. When abundance was incorporated in the analysis of the species similarities between the two substrates, a lower PS value (0.31) was observed. The highest CC value was when the myxomycete assemblage on ground litter collected from the mountain forests was compared with the corresponding value for ground litter collected from the coastal forests (Table 3). However, when relative abundance values were incorporated in the analysis, the highest similarity value was obtained between myxomycetes on ground litter from coastal forests and on twigs from coastal forests (PS $=0.17$ ).

\section{Discussion}

In the study reported herein, the moist chamber culture technique was found to be exceedingly useful in assessing the diversity of myxomycetes in a particular area. This was not surprising, since moist chamber cultures have provided a useful and often very productive method of supplementing field collections in a number of other studies (Novozhilov et al. 2000, Stephenson et al. 2000, Kylin et al. 2013, Lado et al. 2013, Wrigley de Basanta et al. 2013). Seventy percent of the moist chambers yielded positive results for myxomycetes. More fruiting bodies were observed in this study than in the studies of Dagamac et al. (2012) in Mt. Arayat National Park in Pampanga. Moist chamber cultures simulate the environmental conditions (e.g., high humidity) that are necessary for the growth and development of myxomycetes (Keller et al. 2008), and this provides for a better assessment of myxomycete diversity. As already noted, a moist chamber culture positive for myxomycetes (either as plasmodia and/or fruiting bodies) was considered herein as a single collection and these data were used to assess species abundance. In the present study, three moist chamber cultures were prepared from each sample collected. Analysis of the data showed that 
Table 2 Species diversity (Hs), species richness ( $\mathrm{Hg}$ ) and evenness (E) values for myxomycetes in relation to substrates and forest types on Lubang Island. Diversity indices were calculated using the Shannon index (Hs), Gleason index $(\mathrm{Hg})$ and Pielou's index of evenness $(\mathrm{E})$. Note: $\mathrm{GL}=$ ground litter and TW $=$ twigs .

\begin{tabular}{|c|c|c|c|}
\hline & \multicolumn{3}{|c|}{ Parameter } \\
\hline & Hs & $\mathbf{H g}$ & $\mathbf{E}$ \\
\hline \multicolumn{4}{|l|}{ Forest type } \\
\hline Mountain & 1.27 & 5.97 & 0.52 \\
\hline Coastal & 0.99 & 6.16 & 0.38 \\
\hline \multicolumn{4}{|l|}{ Substrate type } \\
\hline GL & 1.10 & 5.56 & 0.43 \\
\hline $\mathrm{TW}$ & 1.04 & 5.18 & 0.41 \\
\hline \multicolumn{4}{|c|}{ Mountain forest } \\
\hline GL & 1.19 & 4.52 & 0.54 \\
\hline TW & 1.06 & 3.87 & 0.50 \\
\hline \multicolumn{4}{|l|}{ Coastal forest } \\
\hline GL & 0.87 & 4.84 & 0.38 \\
\hline TW & 0.89 & 4.37 & 0.39 \\
\hline
\end{tabular}

only $38 \%$ of the triplicate cultures produced the same species of myxomycete in two to three cultures or that all three cultures yielded no myxomycetes. More cultures (62\% of the triplicate cultures) produced different species of myxomycetes or a particular myxomycete was present in only a single culture among the triplicates. This also can be observed when the two types of substrates were compared. This interesting analysis was carried out to show that each of the moist chamber triplicates should be treated as a separate sample so that the productivity of the moist chamber cultures and/or the species of myxomycetes found in the samples were not underestimated and that most - if not all - of the species present in a given sample were likely to have been recorded. In an earlier study, dela Cruz et al. (2014) also noted a higher number of collections and recorded species from all of the triplicate cultures as opposed to recording just those appearing in a single culture.

The productivity of moist chamber cultures also was compared between the two forest types and the two types of substrates. Substrates collected in the mountain forests $(71 \%)$ were more productive for myxomycetes than substrates collected in the coastal forests (69\%). This suggests that general environmental conditions in the mountain forests are more favorable for the growth and development of myxomycetes than is the case in the coastal forests. Between the two substrates, ground litter had the higher yield of myxomycetes. In contrast, although moist chamber cultures prepared with ground litter showed more evidence of myxomycetes in a study in Costa Rica (92\% of the moist chambers produced plasmodia and/or fruiting bodies), $34 \%$ of all specimens collected appeared on twigs and bark substrates. This is interesting, since only $20 \%$ of all of the substrates collected were twigs and bark, which indicates that the latter were more productive than ground litter (Rojas \& Stephenson 2008). Furthermore, it was reported that twigs were the substrate characterized by the highest mean number of fruiting bodies per moist chamber culture (Rojas \& Stephenson 2008). As such, the availability of particular microhabitats can influence myxomycete distribution to a considerable extent (Stephenson 1989). This microhabitat was described as a microecosystem, defined as a small specialized habitat within a larger habitat (Schnittler \& Stephenson 2002). In the present study, the use of the term microhabitat refers to the substrate types with which myxomycetes are associated. Ground litter, contrary to the results reported in some studies, appears to offer a more favorable microhabitat than twigs. This can be attributed to the presence of more potential food resources (e.g., bacteria and other microorganisms) on the decaying leaves that make up much of ground litter. The trophic stages of myxomycetes feed upon 
these bacteria and other microbes.

It was considered worthwhile to assess the diversity and distribution of myxomycete on Lubang Island since this is the first ecological study of myxomycetes in what has been designated as a biodiversity conservation priority area. Moist chamber cultures were used as the primary method of myxomycete diversity assessment, but specimens collected during field sampling were also recorded. Moist chamber cultures have been found to be exceedingly useful in assessing myxomycete diversity in a number of other studies (e.g., Härkönen 1981, Lado et al. 2003, Wrigley de Basanta et al. 2008, Kilgore et al. 2009). In the present study, A. cinerea was the most abundant myxomycetes appearing on both substrates and in both forest types. This observation is not unexpected, since $A$. cinerea is known to have a cosmopolitan distribution and has been reported in virtually all surveys carried out for myxomycetes in both temperate and tropical regions of the world (Stephenson et al. 2004, Tran et al. 2006, Wrigley de Basanta et al. 2013). Diderma effusum also was abundant on ground litter, so were Diachea leucopodia and Physarum cinereum. The other species were recorded as rare on ground litter. A similar result was obtained in a study of myxomycetes associated with different substrates in the state of Arkansas in the United States. Moreover, the highest species composition was noted for ground litter in a study carried out by Eliasson et al. (1988).

No previous studies have attempted to compare the distribution and diversity of myxomycetes in different forest types and on different substrates in the Philippines. Dagamac et al. (2012) documented the composition and abundance of myxomycetes in relation to their collection time, substrates and sites. This represented the most comprehensive study carried out thus far but was limited to one forest type (a lowland mountain forest). Consequently, the present study was the first to compare the species diversity and composition of myxomycetes in relation to the forest types and substrates on a geographically isolated island. When the substrates in relation to the forest types were compared, ground litter from the mountain forests was characterized by the highest S/G ratio, followed by twigs from the mountain forests. The lowest taxonomic diversity was calculated for twigs from the coastal forests. This result is supported by Pielou (1975), who indicated that diversity should be considered higher for a community in which species are distributed among several genera as contrasting to one where most of the species belong to the same genus. Apart from taxonomic diversity, species diversity also was assessed based on the richness and evenness of the myxomycete species in the two forest types and on two substrates (Table 2). Myxomycetes in the mountain forests were found to be more even than in the coastal forests. However, the assemblage of species of myxomycete in the coastal forests was more species rich than the assemblage present in the mountain forests. Overall diversity as reflected by the Shannon's diversity index (Hs) showed a higher value for the mountain forests, but between the two substrates collected, minimal differences in species diversity were observed.

To evaluate the similarities and differences in the myxomycete communities present on Lubang Island, community analysis was carried out by calculating Sorensen's Coefficient of Community (CC) and the Percentage Similarity (PS) values. When the myxomycete assemblages between the two forest types were compared, more than $75 \%$ of the total species identified in both forest types were the same. For the myxomycete communities on the two substrates, more than half of the species occurring on ground litter also occurred on twigs. Interestingly, the highest $\mathrm{CC}$ value was for the comparison of the myxomycete assemblage on ground litter collected from the mountain forests with that on ground litter collected from the coastal forests (Table 3). This implies that there were species common to the same substrate regardless of forest type. However, when relative abundance values were incorporated in the analysis, the highest similarity value was obtained between myxomycetes on ground litter from the coastal forests and twigs from the coastal forests (Table 3). In this case, similarities in the environmental conditions in this forest type presumably accounted this pattern. In contrast, the lowest similarity value was observed between myxomycetes on ground litter and twigs from the mountain forest. A lower PS value also was noted for these two communities when they were compared (Table 3). This implies that in the mountain 
Table 3 Sorensen's Coefficient of Community (lower left) and Percentage Similarity (upper right) values of the myxomycete communities collected at the two substrates from the two forest types on Lubang Island. Note: GL = ground litter and TW = twigs.

\begin{tabular}{|c|c|c|c|c|c|}
\hline & & \multicolumn{2}{|c|}{ Coastal Forest } & \multicolumn{2}{|c|}{ Mountain Forest } \\
\hline & & GL & TW & GL & TW \\
\hline Coastal & GL & $* * *$ & 0.17 & 0.13 & 0.12 \\
\hline \multirow{3}{*}{ Mountain } & TW & 0.54 & $* * *$ & 0.11 & 0.13 \\
\hline & GL & 0.69 & 0.42 & $* * *$ & 0.11 \\
\hline & TW & 0.51 & 0.56 & 0.37 & $* * *$ \\
\hline
\end{tabular}

forests, a different assemblage of myxomycetes occupies a particular substrate. It also implies that although the species composition may be similar for the two communities, these species may not be present in equal abundance. It can be further inferred that myxomycetes in the mountain forests are occurring more randomly than those in the coastal forest. So, as a general observation, the results of this study suggest that more than being forest type specific, the myxomycetes recorded on Lubang Island are more substrate type specific, as shown by the higher number of uncommon species on ground litter and twigs as well as the lower number of uncommon species when the two types of forests were compared.

In summary, the project described herein evaluated the distribution and diversity of the assemblages of myxomycetes associated with ground litter and twigs collected in coastal forests and in mountain forests on Mt. Gonting on Lubang Island. Specimens obtained from moist chamber cultures represented 44 species of myxomycetes belonging to 13 genera. Arcyria cinerea, D. leucopodia, D. effusum, L. scintillans, and P. cinereum were abundant, but the majority of the species recorded were rare. The highest values for taxonomic and species diversity were recorded for ground litter from mountain forests. Myxomycete assemblages were more similar on ground litter and twigs from the mountain forests but were present in unequal abundances. PS values of ground litter and twigs from the coastal forests revealed a greater similarity. As such, it would appear that areas in close proximity support similar assemblages of species of myxomycetes. However, substrate dependency seems to be a major factor affecting these assemblages on Lubang Island.

\section{Acknowledgements}

This research was supported in part by the Mycological Society of America through the Martin-Baker Research Award (2009) and also by the Philippine Council for Advanced Science and Technology Research and Development of the Department of Science and Technology in the Philippines. The authors would like also to thank the local government of Lubang, Occidental Mindoro, and its mayor, the Hon. Juan Sanchez, for providing invaluable support during the collecting of field specimens and substrates. Appreciation is extended to Paul Richard J. Yulo, Nikki Heherson A. Dagamac, Dianne L. Dizon, and Marie Grace B. Lavadia for their technical assistance and aid during the collecting of substrate samples.

\section{References}

Alfaro JRD, Alcayde DLIM, Agbulos JB, Dagamac NHA, dela Cruz TEE. 2015 - The occurrence of myxomycetes from a lowland montane forest and agricultural plantations of Negros Occidental, Western Visayas, Philippines. Fine Focus 1, 7-20.

Cheng CBT, Yu KNT, Campos ML, Adora JMV, Pascua GCP, Pangilinan MVB, Buaya AT, dela Cruz TEE. 2013 - Occurrence and diversity of myxomycetes (plasmodial slime molds) along the northern slope of Mt. Makulot, Cuenca, Batangas, Philippines. Asian Journal of Biodiversity 4, 65-83. 
Colwell RK. 2009 - EstimateS: statistical estimation of species richness and shared species from samples. Version 8.2. User's guide and application. http://purl.oclc.org/estimates.

Dagamac NHA, dela Cruz TEE, Rea-Maninta MAD, Aril-dela Cruz JV, Schnittler M. 2015a Rapid assessment of myxomycete diversity in Bicol Peninsula. Nova Hedwigia DOI: http://dx.doi.org/10.1127/nova_hedwigia/2015/0252.

Dagamac NHA, Rea-Maminta MAD, dela Cruz TEE. 2015b - Plasmodial slime molds of a tropical karst forest, Quezon National Park, the Philippines. Pacific Science 69(3), 407-418.

Dagamac NHA, Stephenson SL, dela Cruz TEE. 2012 - Occurrence, distribution, and diversity of myxomycetes (plasmodial slime molds) along two transects in Mt. Arayat, National Park, Pampanga, Philippines. Mycology: International Journal of Fungal Biology 3(2), 119-126.

Dagamac NHA, Stephenson SL, dela Cruz TEE. 2014 - The occurrence of litter myxomycetes at different elevations in Mt. Arayat, National Park, Pampanga, Philippines. Nova Hedwigia 98, 187-196.

Dela Cruz TEE, Rea MAD, Tran HTM, Ko Ko TW, Stephenson SL. 2014 - A comparative species listing of myxomycetes from tropical (Philippines) and temperate (United States) forests. Mycosphere 5(2), 299-311.

Dogma IJ. 1975 - Of Philippine mycology and lower fungi. Philippine Journal of Biology 4, 69105.

Eliasson UH, Keller HW, Hutchison JA.1988 - Myxomycetes from Arkansas. Mycotaxon 32, 375398.

Härkönen M. 1981 - Gambian Myxomycetes developed on moist chamber cultures. Karstenia 21, 21-25.

Keller HW, Braun KL. 1999 - Myxomycetes of Ohio: Their systematics, biology, and use in teaching. Ohio Biological Survey Bulletin New Series 13(2), 1-182.

Keller HW, Kilgore CM, Everheart SE, Carmack GJ, Crabtfree CD, Scarborough AR. 2008 Myxomycete Plasmodia and Fruiting Bodies: Unusual occurrences and user-friendly study techniques. Fungi 1(1), 24-37.

Kilgore CM, Keller HW, Ely JS. 2009 - Aerial reproductive parts of vascular plants as a microhabitat for myxomycetes. Mycologia 101(3), 305-319.

Kuhn RV, Javier AOM, Rodillas CP, Parra CM, Corpuz LHM, Buaya AT, dela Cruz TEE. 2013 Diversity of plasmodial myxomycetes from Anda Island, Pangasinan, Philippines. Biotropia 20(1), 1-9.

Kuhn RV, Javier AOM, Rodillas CP, Parra CM, Corpuz LHM, Moron LS, dela Cruz TEE. 2013 Occurrence and distribution of plasmodial myxomycetes (slime molds) in three provinces of Luzon Island, Philippines. Philippine Science Letters 6(1), 1-7.

Kylin H, Mitchell DW, Seraoui EH, Buyck B. 2013 - Myxomycetes from Papua New Guinea and New Caledonia. Fungal Diversity 59, 33-44.

Lado C, Estrada-Torres A, Stephenson SL, Wrigley de Bessanta D, Schnittler M. 2003 Biodiversity assessment of myxomycetes from two tropical forest reserves in Mexico. Fungal Diversity 12, 67-110.

Lado C, Wrigley de Basanta D, Estrada-Torres A, Stephenson SL. 2013 - The biodiversity of myxomycetes in central Chile. Fungal Diversity 59, 3-32.

Macabago SAB, Dagamac NHA, dela Cruz TEE. 2010 - Diversity and distribution of plasmodial myxomycetes (slime molds) from La Mesa Ecopark, Quezon City, Philippines. Biotropia 17 (2), 51-61.

Macabago SAB, dela Cruz TEE, Stephenson SL. 2012 - First records of myxomycetes from Lubang Island, Occidental Mindoro, Philippines. Sydowia 64(1), 109-118.

Martin GW, Alexopoulus CJ. 1969 - The Myxomycetes. Illustrated by Ruth McVaugh Allen. University of Iowa Press, Iowa City, 566 pp.

Novozhilov YK, Schnittler M, Erastova DA, Okun MV, Schepin ON, and Heinrich E. 2013 Diversity of nivicolous myxomycetes of the Teberda State Biosphere Reserve (Northwestern Caucasus, Russia). Fungal Diversity 59(1), 109-130. 
Novozhilov YK, Schnittler M, Zemlianskaia IV, Fefelov KA. 2000 - Biodiversity of plasmodial slime molds (Myxogastria): Measurement and interpretation. Protistology 1(4), 161-178.

Ong PS, Afuang LE, Rosell-Ambal RG (eds.). 2002 - Philippine Biodiversity Conservation Priorities: A Second Iteration of the National Biodiversity Strategy and Action Plan. Department of Environment and Natural Resources-Protected Areas and Wildlife Bureau, Conservation International Philippines, Biodiversity Conservation Progam-University of the Philippine Center for Integrative and Development Studies, and Foundation for the Philippine Environment, Quezon City, Philippines, 113 p.

Pielou EC. 1975 - Ecological diversity. Wiley InterScience, New York.

Reynolds DR, Alexopoulos CJ. 1971 - Southeast Asian myxomycetes. I. Thailand and Burma. Pacific Science 25(1), 33-38.

Reynolds DR. 1981 - Southeast Asian myxomycetes II. Philippines. Philippine Journal of Biology $10(2-3), 127-150$.

Rojas C, Stephenson SL. 2008 - Myxomycete ecology along an elevation gradient on Cocos Island, Costa Rica. Fungal Diversity 29, 117-127.

Schnittler M, Stephenson SL. 2002 - Inflorescences of Neotropical herbs as a newly discovered microhabitat for myxomycetes. Mycologia 94, 6-20.

Stephenson SL, Kalyanasundaram I, Lakhanpal TN. 1993 - A comparative biogeographical study of myxomycetes in the mid-Appalachians of eastern North America and two regions of India. Journal of Biogeography 20, 645-657.

Stephenson SL, Novozhilov YK, Schnittler M. 2000 - Distribution and ecology of myxomycetes in high latitude regions of the Northern Hemisphere. Journal of Biogeography 27, 741-754.

Stephenson SL, Schnittler M, Lado C. 2004 - Ecological characterization of a tropical myxomycete assemblage - Maquipucuna Cloud Forest Reserve, Ecuador. Mycologia 96(3), 488-497.

Stephenson SL, Stempen H. 1994 - Myxomycetes: A Handbook of Slime Molds. Timber Press, Portland, Oregon.

Stephenson SL. 1989 - Distribution and ecology of myxomycetes in temperate forests. II. Patterns of occurrence on bark surface of living trees, leaf litter, and dung. Mycologia 81, 608-621.

Tran DQ, Nguyen HTN, Tran HTM, Stephenson SL. 2014 - Myxomycetes from three lowland tropical forests in Vietnam. Mycosphere 5(5), 662-672.

Tran HTM, Stephenson SL, Hyde KD, Mongkolporn O. 2006 - Distribution and occurrence of myxomycetes in tropical forests of northern Thailand. Fungal Diversity 22, 227-242.

Uyenco FR. 1973 - Myxomycetes of the Philippines. University of the Philippines Natural Science Research Center Technical Report 12, 1-23.

Wrigley de Basanta D, Lado C, Estrada-Torres A, Stephenson SL. 2013 - Biodiversity studies of myxomycetes in Madagascar. Fungal Diversity 59, 55-83.

Wrigley de Basanta D, Stephenson SL, Lado C, Estrada-Torres A, Nieves-Rivera A. 2008 - Lianas as a microhabitat for myxomycetes in tropical rainforests. Fungal Diversity 28, 109-125. 